\title{
Influence of local factors on methods of orthodontic treatment in patients with external radicular resorption
}

\author{
Influenţa factorilor locali asupra metodelor de tratamentul ortodontic la \\ pacienţii cu resorbţie radiculară externă
}

\author{
Anca Nicoleta Temelcea', Paula Perlea², Irina Maria Gheorghiu², \\ Alexandru Andrei Iliescu ${ }^{3}$ \\ ${ }^{1}$ Disciplina de Tehnică Dentară, Facultatea de Moaşe şi Asistenţă Medicală, \\ Universitatea de Medicină şi Farmacie „Carol Davila“, Bucureşti, România \\ ${ }^{2}$ Disciplina de Endodonţie, Facultatea de Medicină Dentară, \\ Universitatea de Medicină şi Farmacie „Carol Davila“, Bucureşti, România \\ ${ }^{3}$ Disciplina de Reabilitare Orală, Facultatea de Medicină Dentară, \\ Universitatea de Medicină şi Farmacie, Craiova, România
}

\begin{abstract}
Orthodontic treatment should solve dental-maxillofacial disorders respecting as far as possible the conservative biological principles of the dental substance.

Dosage of orthodontic forces must be made according to the intended therapeutic objective, but without jeopardizing the dental implantation or aggravating the root injury, if it is already installed.

The prognosis of evolution in these cases is reserved and limited by the possibilities of repairing the root injuries.
\end{abstract}

Keywords: orthodontic force dosing, external root resorption, root repair

\section{REZUMAT}

Tratamentul ortodontic trebuie să rezolve tulburările aparatului dento-maxilar, respectând, pe cât posibil, principiile conservatoare biologice ale substanţei dentare.

Dozarea forţelor ortodontice se impune a fi făcută în funcţie de obiectivul terapeutic urmărit, dar fără a pune în pericol implantarea dentară sau a agrava afectarea radiculară, în situaţia în care aceasta este deja instalată. Prognosticul de evoluţie în aceste cazuri este rezervat şi limitat de posibilităţile de reparaţie a leziunilor radiculare.

\section{Cuvinte cheie: dozarea forţelor ortodontice, resorbţie radiculară externă, reparaţie radiculară}

Unul dintre obiectivele generale ale tratamentului ortodontic este reprezentat de rezolvarea dezechilibrelor produse la nivelul aparatului dento-maxilar de diferitele tipuri de anomalii dento-maxilare, în limite fiziologice, fără sacrificii biologice inutile.

Pentru exemplificarea aspectelor practice legate de tratamentul ortodontic la pacienți care prezintă dinţi cu resorbție radiculară externă de cauză trau- matică, exercitată prin presiunea formațiunilor învecinate, articolul de față îşi propune să prezinte un caz clinic relevant pentru această tipologie.

Pacientă în vârstă de 12 ani, de sex feminin, din mediul urban, se prezintă la un cabinet de medicină dentară, pentru consultaţie şi tratament de specialitate.

Pacienta acuză, la momentul prezentării, ,lipsa de erupție a dinţilor de lapte”, ca motiv al prezentării. 


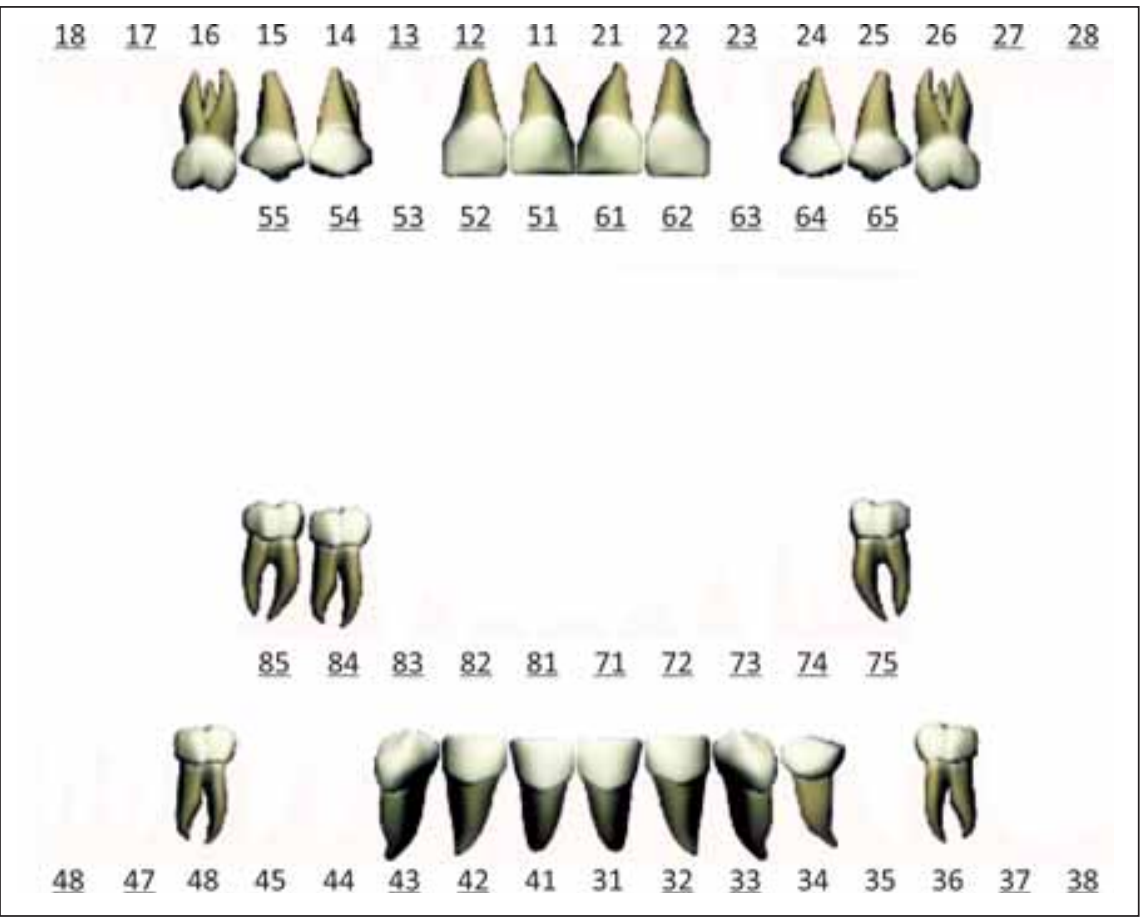

FIGURA 1. Formula dentară a pacientei la începutul tratamentului ortodontic

Examenul clinic intraoral decelează o dentiție mixtă, cu persistența pe arcadă a molarilor 2 temporari inferiori 75 şi 85 , aflaţi în reincluzie, şi a molarului 1 temporar inferior de pe partea dreaptă 84 (Fig. 1).

La nivelul maxilarului se remarcă lipsa de pe arcadă a caninilor definitivi, cu închiderea completă a spațiului de erupție la nivelul lui 13 şi diminuarea semnificativă a acestuia la nivelului lui 23 .

Examinarea clinică a fost completată de investigațiile paraclinice, reprezentate în cazul nostru de ortopantomogramă, teleradiografie de profil, radiografii dentare de detaliul la nivelul crestei alveolare din dreptul 13, 23, fotografii de diagnostic ortodontic şi modele de studiu.

Analiza ortopantomogramei ne-a evidențiat caninii superiori definitivi rămaşi în incluzie intraosoasă în poziție înaltă 13 sau în incluzie submucoasă 23. Se remarcă, de asemenea, un grad important de resorbție radiculară externă de cauză traumatică la nivelul incisivului lateral superior definitiv de pe partea stângă 22, precum şi un stadiu incipient de afectare radiculară la nivelul omologului de pe partea dreaptă. Molarii de 6 ani din toate cadranele prezintă diferite grade de afectare radiculară prin resorbție, determinată de mugurii molarilor de 12 ani, blocaţi în erupție cel mai probabil din cauza lipsei de spațiu manifestată şi la acest nivel. Mugu- rii molarilor de minte sunt prezenți intraosos, în diferite grade de dezvoltare. Pacienta nu prezintă mugurii premolarilor 2 inferiori, nici pe partea stângă 35 şi 45, nici pe partea dreaptă. Modelul de creştere mandibular este de tip hipodivergent (Fig. 2).

Pe teleradiografia de profil (Fig. 3) se confirmă modelul de rotație de tip anterior la nivelul mandibulei, precum şi direcția de erupție a caninului superior de pe partea dreaptă 13, în raport strâns de vecinătate cu rădăcina incisivului lateral de la acel nivel 12.

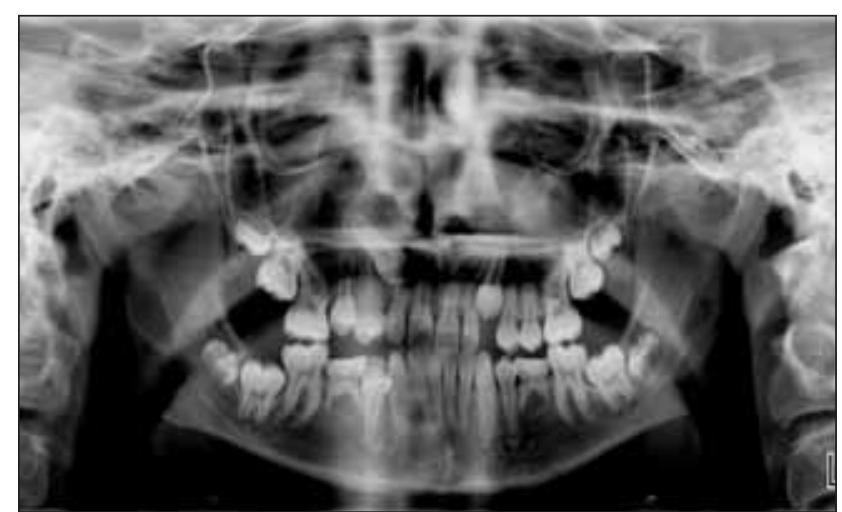

FIGURA 2. Ortopantomograma pacientei la începutul tratamentului ortodontic

Pe radiografia retroalveolară se poate observa gradul important de rizaliză a rădăcinii incisivilor laterali (care la nivelul lui 22 a afectat $2 / 3$ din rădăcină), precum şi chisturile foliculare de dimensiuni 
considerabile, atât la nivelul lui 23, cât şi la nivelul lui 13 (Fig. 4).

Diagnosticul ortodontic a fost de anomalie de clasa II/1, anodonție de premolari 2 inferiori $(35,45)$, incluzie de canini superiori $(13,23)$, incongruență dento-alveolară cu înghesuire.

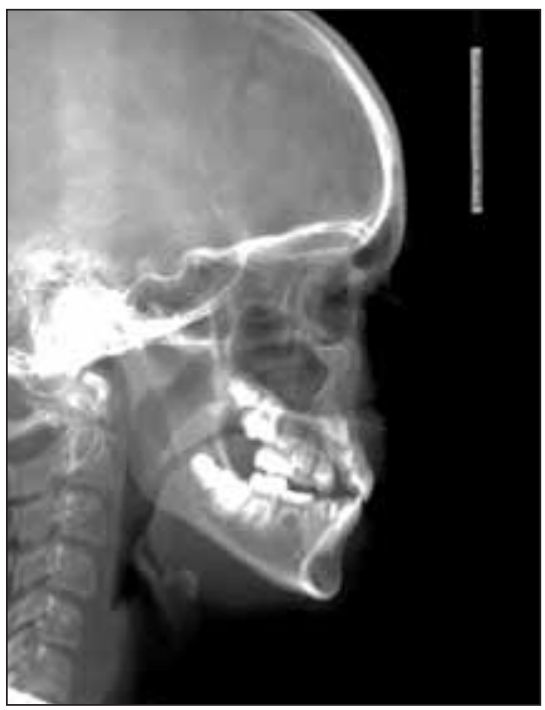

FIGURA 3. Teleradiografia de profil la începutul tratamentului ortodontic

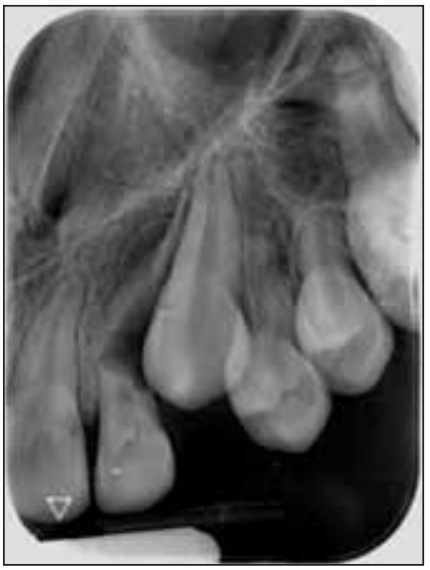

FIGURA 4. Radiografia retroalveolară 22, 23 la începutul tratamentului ortodontic

Primul obiectiv terapeutic a fost reprezentat de crearea de spațiu pentru erupția şi alinierea pe arcadă a caninilor superiori, cu modificarea poziției de evoluție intraosoasă, astfel încât să eliminăm raportul intim de vecinătate cu rădăcinile incisivilor laterali, îndepărtând cauza principală de rizaliză a rădăcinilor acestora.

Pentru primul timp al tratamentului ortodontic s-a aplicat un dispozitiv de expansiune maxilară rapidă (disjunctor) ancorat prin cimentare pe molarii de 6 ani superiori şi prin colaj pe zonele laterale (până la premolarii 1 superiori). Ritmul de activare a fost de $1 / 4$ ture pe zi, timp de 18 zile consecutive. La finalul fazei active s-au obținut 7,2 $\mathrm{mm}$ de spațiu în sens transversal şi s-a modificat, pe cale de consecință, direcția de erupție a caninilor superiori, mai evident pe partea stângă (Fig. 5).

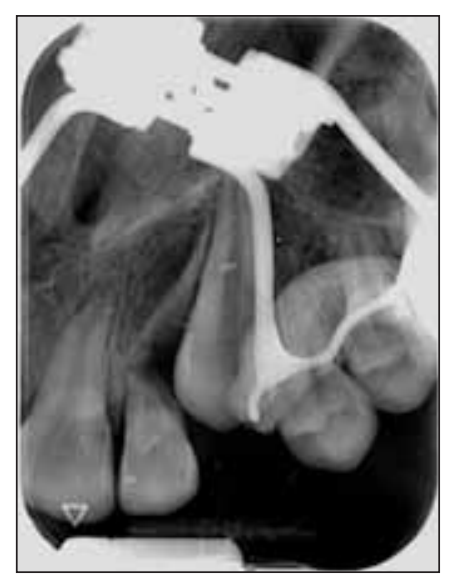

FIGURA 5. Retrografia retroalveolară la finalul etapei de disjuncție. Se poate observa că incisivul lateral a fost scos din aria de acțiune a caninului superior, iar procesul de resorbție radiculară s-a oprit în evoluție, în momentul în care a fost îndepărtat factorul cauzator

Pacienta este în contenție după faza de disjuncție. În timpul doi al tratamentului ortodontic, se va aplica un aparat fix poliagregat care va drept scop alinierea dentară şi corectarea relațiilor de ocluzie (1). Din cauza particularităților de teren (resorbție radiculară externă), pe incisivii laterali nu se vor cola bracket-uri, pentru a nu exercita asupra acestor dinți nici un fel de forțe ortodontice cu potențial de acțiune asupra rădăcinilor (1).

În ceea ce priveşte încercarea de menţinere pe arcadă a incisivilor laterali compromişi din punct de vedere al integrităţii radiculare, s-a optat pentru un tratament endodontic cu pastă MTA (2), care va fi coroborat cu aplicarea unor sisteme de imobilizare din fibră de sticlă fără acțiune ortodontică asupra acestor dinți.

\section{CONCLUZII}

Tratamentul ortodontic prezintă particularități în funcție de terenul pacientului şi trebuie adaptat, din punctul de vedere al momentului intervenţiei şi al dozării forțelor, la caracteristicile specifice fiecărui caz în parte $(4,6)$.

Eliminarea factorilor cauzali ai resorbției radiculare nu determină decât încetarea fenomenului, dar nu produce şi reparația radiculară pe zona afec- 
tată (5). Este însă necesar tratamentului endodontic adjuvant tratamentului ortodontic.

Tratamentul endodontic în situația unor dinţi care prezintă resorbție radiculară de cauză trauma- tică $(3,5)$ poate să constituie o soluție de conservare a acestora pe arcadă un timp îndelungat.

Mențiune: Toți autorii au contribuții egale.

Conflict of interest: none declared Financial support: none declared

\section{BIBLIOGRAFIE}

1. Temelcea A.N., Perlea P., Gheorghiu I.M., Iliescu Al. Particularităţile tratamentului ortodontic la pacienţii cu resorbţie radiculară externă de cauză traumatică fundamentare teoretică, Revista Română de Stomatologie Vol. LXIII, nr. 3, 2017

2. American Association of Endodontics, Glossary of endodontic terms, 2014

3. Perlea P., Nistor C.C., Iliescu Al., Tuculină M.J.

Tratamentul endodontic în rezorbţia radiculară inflamatorie cu localizare apicală, Revista Română de Stomatologie - Vol. LXI, nr. 1, 2015

4. Herrera D.R., Herrera C.M., Lima A.R., Nagata J.Y., Pereira A.C., Silva E.J., Adriana J. Soares, Brenda P. Gomes.
Repair of apical root resorption associated with periodontitis using a new intracanal medicament protocol, Journal of Oral Science, Vol. 56, No. 4, 311-314, 2014

5. Suciu I., Voiculeanu M., Gheorghiu I.M., Perlea P. Evoluţia resorbţiei radiculare externe inflamatorii de cauză traumatică. Caz clinic. Revista Română de Stomatologie - Vol. LXII, nr. 1, 2016

6. Bakland L.K., Andreasen J.O. Biological considerations in the management of traumatic dental injuries, Endodontic Topics, 30, 44-50, 2014 